\title{
How do banks interact with fintech startups?
}

\author{
Lars Hornuf $(\mathbb{D}$ - Milan F. Klus • Todor S. Lohwasser • \\ Armin Schwienbacher
}

Accepted: 27 April 2020 / Published online: 13 May 2020

(C) The Author(s) 2020

\begin{abstract}
The increasing pervasiveness of technologydriven firms that offer financial services has led to growing pressure on traditional banks to modernize their core business activities and services. Many banks tackle the challenges of digitalization by cooperating with startup firms that offer technology-driven financial services and novel service packages (fintechs). In this article, we examine which banks typically collaborate with fintechs, how intensely they do so, and which form of alliance they prefer. Using hand-collected data covering the largest banks from Canada, France, Germany, and the United Kingdom, we provide detailed evidence on the different forms of alliances occurring in practice. We show that banks are significantly more likely to form
\end{abstract}

\author{
L. Hornuf $(\square)$ \\ University of Bremen, Bremen, Germany \\ e-mail: hornuf@uni-bremen.de \\ L. Hornuf \\ Max Planck Institute for Innovation and Competition, Munich, \\ Germany \\ L. Hornuf \\ CESifo, Munich, Germany \\ M. F. Klus · T. S. Lohwasser \\ University of Münster, Münster, Germany \\ A. Schwienbacher \\ SKEMA Business School - Université Côte d'Azur, Euralille, \\ France
}

alliances with fintechs when they pursue a well-defined digital strategy and/or employ a chief digital officer. Moreover, in line with incomplete contract theory, we find that banks more frequently invest in small fintechs but often build product-related collaborations with larger fintechs.

Keywords Fintech · Strategic alliance $\cdot$ Make, buy, or ally Entrepreneurial finance $\cdot$ Banks

JEL classification G21 · G23 · G34 · M13 · L26

\section{Introduction}

In the past two decades, digitalization has influenced many industries, offering new entrepreneurial opportunities and creating new systems of innovation (Barrett et al. 2015; Autio et al. 2018). Most recently, the banking industry, one of the most traditional and conservative sectors in the economy, has been confronted with potentially disruptive technologydriven innovations and Internet-based solutions (Navaretti et al. 2017). By developing new information technology-(IT-) enabled service models, startup firms and multinational technology companies have in many cases created more customeroriented and user-friendly digital applications in the banking industry, leading to growing digital 
servitization of financial products. ${ }^{1}$ Many of these new banking solutions have also been developed by financial technology (fintech) companies. Some of the new digital innovations have the potential to reshape or even crowd out some of the business activities of more traditional banks. As a result, digitalization and platform-enabled fintechs have forced banks to reconsider their corporate boundaries and make them more permeable to market interactions (Kohtamäki et al. 2019). More permeable organizational forms such as strategic alliances allow banks to confront the threat of technologydriven firms and offer traditional banks new advantages to benefit from innovations developed by fintechs in ways different from the simple "makeor-buy" decision (Borah and Tellis 2014; Jacobides and Billinger 2006). For example, banks have established fintech incubators and accelerators to enable innovations while maintaining control through a minority share in the firms that are built or supervised.

A lack of legacy infrastructure and comparatively low level of organizational complexity often enable fintech firms to be more agile, innovate faster, and be more radical in their approach to innovation (Brandl and Hornuf 2020). By contrast, it is more difficult for traditional banks to adapt to some of the new technological developments because they need to comply with more extensive regulatory requirements. Often, a larger number of stakeholders need to be convinced when adopting far-reaching organizational changes in a traditional bank (Klus et al. 2019). Moreover, digital service innovations typically crowd out banks' existing distribution channels (Vendrell-Herrero et al. 2017), thereby reducing banks' incentives to introduce new distribution channels on their own. The sluggishness of traditional banks to

\footnotetext{
${ }^{1}$ For an empirical structuring of the servitization literature, see the study of Rabetino et al. (2018). In a classic sense, digital servitization refers to "the provision of digital services embedded in a physical product" (Vendrell-Herrero et al. 2017, p. 69), a definition that is based on research conducted in the manufacturing industry (Coreynen et al. 2017; Kohtamäki et al. 2019). The financial industry views the term "product" more broadly, as financial products do not physically exist. In the financial industry, servitization refers to the way financial products are now offered and brokered. New services became available for traditional financial products that did not exist a decade ago and were enabled by digitalization. For example, application programming interfaces allow fintechs to screen the number of bank customers and to offer new services, such as account switching or the automated switching or termination of an agreement, based on the information from the account and the algorithms the fintech developed.
}

adapt to digital challenges not only has implications at the individual bank but also affects the entire financial ecosystem. Given the legacy infrastructure and high level of organizational complexity inherent in many banks, they need to re-organize their ecosystem to improve the digital services offered to retail and business clients (for related work on multinational industries, see Sklyar et al. (2019).

In this article, we analyze which characteristics of banks are associated with different forms of alliances with fintech companies. The Financial Stability Board of the Bank for International Settlements defines fintech as "technologically enabled financial innovation that could result in new business models, applications, processes, or products with an associated material effect on financial markets and institutions and the provision of financial services" (European Banking Authority 2017, p. 4). We are particularly interested in the number of bank-fintech alliances that have been established in developed economies and the factors related to different forms of alliances such as investments or productrelated collaborations. Finally, we investigate the impact of these alliances on banks' market value. ${ }^{2}$

The literature on financial innovation in general and bank-fintech alliances in particular is scarce. First, our analysis contributes to the empirical literature on financial innovation. Lerner (2002) and Miller (1986) provide empirical evidence that financial innovation, as measured by the filing of financial patents, has been increasing since the late 1970s. Moreover, Scott et al. (2017) find that the financial industry had historically spent a large share of expenses on IT, which reached more than one-third of all expenses in 1992. One reason for the high share of IT expenses was that the financial industry employed computers early on as part of their business model. Historically, innovations (e.g., the automated teller machine) have led to changes in financial organizations and services (Merton 1995). The quality of financial patents and financial innovations was, nevertheless, often low (Lerner et al. 2015). Therefore, the

\footnotetext{
In this article, we use the term "alliance" to refer to any type of interaction between fintech startups and banks. This term is widely used in the "make, buy, or ally" literature (Borah and Tellis 2014; Jacobides and Billinger 2006). As will become clear, alliances comprise minority and majority investments, product-related collaborations, and some other forms. Thus, alliances cover a broad spectrum of possible interactions with fintechs. While some of the terms used here differ somewhat from those in Hagedoorn and Duysters (2002), overall, we take a similar approach in the context of externally sourcing innovative capacities.
} 
financial industry was perceived as one of the least innovative. Still, scant empirical research has investigated whether fintech startups have pressured traditional banks to innovate or even forced banks to engage in strategic alliances with them. We fill this gap in the literature by analyzing bank characteristics that are associated with different forms of alliances with fintech companies.

Second, our analysis contributes to the emerging literature investigating not only individual business models but also the fintech market in its entirety. Haddad and Hornuf (2019) analyze fintechs in 55 countries and provide evidence that markets witness more fintech formations when the economy is well-developed and venture capital is easily accessible. Other relevant factors for the formation of fintechs are access to loans, secure Internet servers, mobile telephone subscriptions, and a large labor force. Cumming and Schwienbacher (2018) find that differences in the enforcement of financial regulations of startups and banks after the financial crisis contributed to venture capital investments in fintech startups. Puschmann (2017) provides a model to categorize the industry. Navaretti et al. (2017, p. 17) conduct a conceptual analysis on the relationship between fintechs and banks and find that the "game is still open" and "a lot of work lies ahead" for the industry.

A related article to ours is that of Brandl and Hornuf (2020), who run a bank-fintech network analysis for Germany and find that most relationships are productrelated collaborations. They argue that this is because most fintechs develop an algorithm or software solution, the value of which can only be determined over time, when the software has been adapted more thoroughly to customer needs. We add to their findings by investigating the particular bank characteristics associated with a bank-fintech alliance. These alliances occur against the backdrop that the arrival of fintechs modifies the supply chain interdependency of banks and thus also establishes new ecosystems (Kohtamäki et al. 2019; Vendrell-Herrero et al. 2017). More precisely, we consider different forms of alliances, such as productrelated cooperation and minority and majority equity stakes, which tend to be classified in the transaction cost literature as "hybrid structures" (Jacobides and Billinger 2006; Williamson 1991), and investigate bank characteristics (e.g., profitability) associated with these alliances.

Finally, we also contribute to the "make, buy, or ally" literature (Borah and Tellis 2014; Jacobides and Billinger 2006), which evidences a broad range of interactions that firms can have with other firms in the market, particularly in the context of innovation management. In particular, our results on why certain types of alliances occur (e.g., investments vs. product-related collaborations) are consistent with incomplete contract theory (Aghion and Bolton 1992; Grossman and Hart 1986). In a broad sense, we also contribute to research on servitization, especially the service science stream of the literature that Rabetino et al. (2018) identifies and that focuses on business-oriented approaches to servitization (e.g., Baines et al. 2009), the systematic development of new services (e.g., Bullinger et al. 2003), and the role of organizational, technological, and human factors in the configuration of new services (e.g., Spohrer et al. 2007; Vargo and Lusch 2011). The financial industry is a relevant sector to examine in this context, given the new service strategies banks and fintechs are currently developing, the additional services incumbents and new market participants add to existing financial products, and the novel service packages now being offered by platforms such as Bó, Mettle, and N26.

Digital servitization in the banking industry initiated an evolving ecosystem that results from the digitalization of financial products and new IT-enabled service models. Industries affected by digital servitization typically confront upstream and downstream competition (Barrett et al. 2015); the current changes in the financial industry also affect both upstream (through new services and service packages offered) and downstream (through enhanced customer services and novel distribution channels) competition. In the former case, disintermediated finance solutions such as crowdfunding give retail investors access to new investment products. In the latter case, the emergence of various platforms that allow customers to directly compare prices of different banks has modified how financial products are offered and distributed.

The structure of this article is as follows: In the "Literature review and hypotheses" section, we outline our theory and hypotheses, and in the "Data and methods" section, we describe our data and the methods applied. In the "Empirical results" section, we present the results. The "Discussion" section provides an analytical discussion, and the "Conclusion" section concludes with implications for practice, and outlines avenues for future research. 


\section{Literature review and hypotheses}

To increase their profitability, banks have historically developed financial innovations (Scott et al. 2017) and more recently embraced digital services as a new engine of growth (Barrett et al. 2015). Beck et al. (2016) show that financial innovations are positively associated with bank growth. The recently emerging service science literature also suggests that the development of new service models can reduce costs to firms and add value to customers (e.g., Sakao and Shimomura 2007). Similar to the recent transformation of century-old business models in the computer equipment and software industry, new IT-enabled service models and digital servitization are likely to enhance the financial performance of incumbent firms in the banking industry (Kohtamäki et al. 2020; Spohrer and Maglio 2010). Moreover, novel digital infrastructures such as the blockchain technology can facilitate the combinatorial potential for enhanced service innovations (Yoo et al. 2010). In their study on 50 Swedish advanced service providers, Sjödin et al. (2019) examine how relational governance for the provision of advanced services can enhance the financial performance of a firm. They identify a need to apply a set of diverse relational governance strategies to generate superior financial performance. In line with these findings, we derive testable hypotheses about what drives bank-fintech interactions under the premise that alliances are the result of mutually beneficial transactions between banks and fintechs (Coase 1960; Scott et al. 2017). These transactions are meant to enhance the bank's value through the implementation of financial innovations. In other words, bank-fintech alliances aim to improve the market value of both fintechs and banks.

While early research on the boundary of firms primarily considered market transactions versus the acquisition of firms, and thus the internalization of externally developed products or services (starting with Coase 1937), recent research on organizations has evidenced various other forms of interactions that could lead to alliances for the joint development of products or services and the exploitation of innovation opportunities (Borah and Tellis 2014; Jacobides and Billinger 2006). Current innovations pose particular challenges to the optimal boundary of banks, for which market transactions could provide more flexible solutions to the increasing digitalization of organizations and the emergence of platform-based business models in the financial industry. If banks cannot develop new digital services themselves to reap the benefit of digitalization, they must adopt a more permeable structure that facilitates interactions with fintechs to better match financial service capabilities with the particular needs of the market.

Fintechs might collaborate with banks for several reasons. Through an alliance with an established player in the financial industry, fintechs can obtain access to a broader customer base, gain access to superior knowledge in how to deal with financial regulations, and improve their own digital services. Some fintechs engage in an alliance with a bank to obtain access to a banking license, which in many cases would be too cumbersome and too expensive for a fintech startup to obtain (Klus et al. 2019). By contrast, banks can secure a competitive advantage by collaborating with fintechs that are developing or have already developed a better way to provide financial services. In some cases, investing in a fintech firm can give a bank the exclusive rights to use a specific application or license, enabling it to exclude competitors at its discretion. Similar to industrial firms, banks can thus protect their core businesses (Hagedoorn and Duysters 2002). Moreover, such an investment allows the bank to exercise control and directly influence the product development process and service strategies of the fintech.

Given the opportunities and challenges associated with the digital transformation of the financial industry, the majority of banks have by now adopted a digital strategy that outlines how digital transformation should occur. One way to execute this transformation is to assign responsibility for this process to a designated manager, and some banks have thus created the position of a chief digital officer (CDO). While research has examined the role of the chief executive officer and chief financial officer in earnings management (Jiang et al. 2010) and explored whether hiring a chief financial officer changes fraudulent financial reporting (Geiger and North 2006), little is known about the role of the CDO. This lack of research is likely due to the recent creation of this new board position. Given the specific tasks assigned to the $\mathrm{CDO}$ and the context in which this position has been created, the CDO may predominantly develop in-house digitalization competencies as well as new service strategies and collaborate with fintechs only if doing so is the most cost-efficient solution. However, ceteris paribus, a bank with a $\mathrm{CDO}$, may also interact more frequently with fintechs than banks without such a 
position because initiating alliances with fintechs could simply be part of the same corporate change strategy.

If CDOs implement strategies to develop new digital services within the bank, they might also be more likely to pursue organizational changes that make banks more permeable to the market to reap the full benefits of the new services, thus making interactions with fintechs more likely. These interactions may take the form of an investment or a product-related collaboration. Alliances enable banks to benefit from innovations without facing the burden of having to develop them in the presence of existing organizational structures and legacy IT systems. A clear mission of a CDO and the reduced burden to innovate in the absence of a legacy system thus lead banks with a CDO to launch more alliances. Similarly, some banks do not hire a CDO but nevertheless develop a clear digital strategy and delegate the development of this strategy to other managers of the bank. As this may lead to the same outcome, we conjecture that banks with a clear digital strategy are more likely to have alliances with fintechs than banks without such a strategy. We summarize these predictions as follows:

H1 (CDO or digital strategy): banks with a CDO or that have defined digitalization as a goal in their corporate strategy are more likely to establish alliances with fintechs.

Banks have different motives when they engage in an alliance with a fintech. The development of digital services affects how financial products look and how they are distributed to customers. If banks cannot develop new digital services themselves because of their IT legacy and organizational structure, product-related collaborations enable them to broaden their portfolio and use alternative distribution channels to reach new customers. Offering fintech services or applications on their websites helps banks maintain their customer base without having to develop new services or applications themselves. Often, developing these services or applications alone is a cumbersome task because many banks operate software systems that are barely compatible with modern end-user applications and suffer from organizational legacy (Brandl and Hornuf 2020). Moreover, because many fintechs offer software solutions, which must be customized to end-user needs and updated at regular intervals, acquiring a fintech is risky for a bank. Whether a fintech can develop efficient digital services in a timely manner is uncertain, and having the option to choose the software of another provider can be a riskminimizing strategy for a bank. Waiting until the digital service of a fintech has been customized and is running in the mass market that might therefore be a better strategy. By acquiring a fintech early on in the development or even commercialization phase, banks can easily bet on the wrong horse. In such a situation, taking the route of setting up alliances may allow the bank to reduce technological and market risk. As the make, buy, or ally literature indicates (Borah and Tellis 2014; Jacobides and Billinger 2006), alliances can therefore represent a more flexible solution particularly suitable for innovations.

The relative benefits of setting up an alliance with an existing fintech startup rather than acquiring it are factor specific, as not all banks will benefit equally from forming an alliance. Strategic alliances may also fail to generate superior financial performance, notably because banks and/or fintechs lack specialized knowledge or proper decision-making authority to operate successfully within a novel financial ecosystem (Das and Teng 2000; Li et al. 2019). If, however, banks wait too long, given the competitive environment in which they are evolving, they might lose a valuable innovation to a competitor, something banks may be able to shield themselves against by acquiring the startup early on. Large banks often have deeper pockets than small banks and can also bear the risk of acquiring the wrong fintech. An investment, through either a minority or majority acquisition, in a fintech allows banks to internalize the knowledge of the fintech better and obtain sole possession of its knowledge (Teece 1986). We, therefore, expect bank size to be associated with the form of alliances chosen and conjecture the following:

H2a (type of alliance): large banks are more likely to invest in fintech firms, while small banks engage in product-related collaborations.

In the context of innovation, the theoretical literature on incomplete contracting has developed strong arguments on the choice between building corporate, collaborative relationships governed by contracts and acquiring the innovating firm (Grossman and Hart 1986). Innovation activities are typically difficult to contract because their ultimate outcome is hard to determine $e x$ ante and thus is non-verifiable ex post (Aghion and Bolton 1992). This is especially true for early-stage 
firms, in which the ultimate outcome of an innovation is still largely unknown. In this case, contracting between the fintech and the bank is not an effective way of generating synergies because the fintech cannot be contractually constrained in creating synergies with the bank. When contract terms about future innovations cannot clearly be written down, ex post enforcement becomes impossible. Consequently, investing in the fintech is superior to a product-related cooperation because it allows the bank to control the decisions made inside the fintech firm more directly.

H2b (type of alliance): banks are more likely to invest in small fintechs and engage in productrelated collaborations with large fintechs.

After analyzing the characteristics of alliances, an important question is whether the alliances between banks and fintechs ultimately create economic value. Because many banks have only recently engaged in alliances with fintechs, it is still too early to investigate the effect of these alliances on long-term performance measures of banks or even their corporate structure. Nevertheless, event studies are an established method to evaluate the market expectations of future cash flows that might result from organizational changes, such as mergers, joint ventures, or strategic alliances (Amici et al. 2013; Gleason et al. 2003; Marciukaityte et al. 2009). Given the increasing importance of digitalization for the financial industry and its impact on the survival of incumbent banks, we expect markets to react to announcements of bank-fintech alliances. If stock prices reflect future earnings of banks and if strategic alliances with fintechs are value enhancing, for example, through superior digital servitization strategies, this should be reflected in the market valuation of the involved bank.

H3 (economic value): announcements of bankfintech alliances have a positive impact on the market value of the bank.

\section{Data and methods}

To test our hypotheses, we follow a quantitative approach. Although a qualitative approach would have been equally valid, we were interested in the extent of bank-fintech alliances and wanted to compare them across different countries and financial subsectors. We therefore hand-collected detailed information on alliances formed by the hundred largest banks in Canada, France, Germany, and the United Kingdom between 2007 and 2017. In this section, we present our data, describe the methods used, and outline our empirical models.

\subsection{Data}

Our initial sample consists of the hundred largest legally independent banks, as measured by their total assets, in each of the following four countries: Canada, France, Germany, and the United Kingdom. The list of banks came from the respective national supervisory authorities and comprises all active banks as of 2017. We chose these four countries because they represent different financial systems: while Canada and the United Kingdom are traditionally considered market-based financial systems, France and Germany are considered bankbased financial systems (Demirguc-Kunt and Levine 1999). Furthermore, the four countries are similar in size, allowing us to provide a comprehensive overview of the respective market. We deliberately decided not to analyze countries with a large fintech market, such as China and the USA, because our results might have been less comprehensive, and our language proficiency (in the case of China) would not have been sufficient for a rigorous analysis. Finally, these two countries would have been outliers that would have skewed the findings of the empirical analysis (Haddad and Hornuf 2019).

To assemble a comprehensive overview of existing bank-fintech alliances, we used a broad Internet search encompassing four steps. First, we searched all bank websites to find official press releases about alliances with fintechs. The decision as to whether the respective partner is a fintech was based on the definition provided by the Financial Stability Board of the Bank for International Settlements. Second, we investigated the fintech side and searched the Crunchbase database for alliances with banks. Third, we ran a comprehensive search for news articles about bank-fintech alliances on Factiva, which also helped us obtain more information on the respective forms of alliances. To ensure that no alliance was omitted, we carried out a systematic 
Google search in the fourth step. ${ }^{3}$ For coding purposes, an alliance counted as an investment if the bank made a minority or majority acquisition and a product-related collaboration if it formed a contract-based partnership. To be included in our sample, three additional requirements needed to be met: (1) the alliance must have been announced between January 1, 2007, and January 1, 2018; (2) at least one bank was involved in the alliance together with at least one fintech; and (3) the bank was located in one of the four studied countries; fintech firms, however, could be located anywhere in the world. Our sample consists of 400 banks that formed 500 bank-fintech alliances. Figure 1 presents an overview of the emergence of bank alliances with fintechs by country and year. The figure shows the cumulative number of alliances in each year and evidences that banks from the United Kingdom formed fintech alliances early on. Our data suggest a perceptible increase for all other countries from the year 2013 onward. During an average year, every 10th bank has engaged in an alliance with a fintech. However, there is a strong variation among banks, with some initiating up to 51 alliances during the sample period and others initiating none.

To investigate which banks collaborate with fintechs and to what extent they do so, we defined two dependent variables: (1) a binary dependent variable Alliance, which equals 1 if bank $i$ has made at least one alliance with a fintech in year $t$ and 0 otherwise, and (2) the number of new alliances (Number of New Alliances) that bank $i$ has begun in year $t$. To test Hypothesis 1 , our two main explanatory variables are the dummy variables Digital Strategy, which equals 1 if bank $i$ has a digital strategy in year $t$ and 0 otherwise, and CDO, which equals to 1 if bank $i$ employs a CDO in year $t$ and 0 otherwise. We handcollected both variables through a systematic analysis of the banks' annual reports and their websites. ${ }^{4}$ The year in

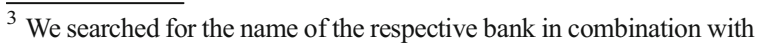
"fintech," "partner," "alliance," "invest," "acqui," and "collabor" and entered wildcard search symbols such as * in combination with these search terms.

${ }^{4}$ Annual reports and websites were frequently available in English. If the information about the variable Digital Strategy was only available in a foreign language, we searched for the French and German equivalents (e.g., stratégie de numérisation, Digitalisierungsstrategie). We consulted an independent researcher fluent in English, French, and German, who validated the terminology and confirmed that the variable was correctly coded. As "chief digital officer" and its abbreviation "CDO" are internationally established terms, we did not perform additional search or validation for these terms in the respective foreign language.
}

which a CDO joined the board came from the banks' annual reports, their websites, and LinkedIn profiles. As the core task of a CDO is to design and support technology-driven process changes, the time-varying variable $C D O$ provides an indicator of the digital orientation of a bank. We treat the bank as having adopted a digital strategy if it has officially declared a strategy to foster digitalization. More specifically, the time-varying variable Digital Strategy indicates whether or not a bank has a welldefined digital strategy. We obtained the variable by analyzing the annual reports of all banks during our sample period. According to our definition, a bank only follows a digital strategy if it has announced an explicit digitalization-related implementation plan; general statements on the importance of digitalization are not enough. From the year the bank first announced a digital strategy, we presume that it continued with this strategy and coded the variable Digital Strategy.

We consider various control variables that have recently been used in the banking literature (Peng et al. 2017). These include firm characteristics, such as whether the bank is publicly listed (Bank Listed) or a universal bank (Universal Bank), and financial indicators, such as the natural logarithm of total assets (In(Bank Total Assets)), the loan-toasset ratio (Bank Loan-to-Asset Ratio), and return on average assets (Bank ROAA). General information about the banks, such as balance sheet data, came from the banks' annual reports and the Fitch Connect database. However, we could only collect some information, such as financial data of privately owned banks, if banks were subject to some form of disclosure requirement. Finally, we collapsed the data into a panel dataset for the 20072017 period to obtain bank-year observations.

To test Hypotheses $2 \mathrm{a}$ and $2 \mathrm{~b}$, we focus on our sample of 500 bank-fintech alliances and create the dummy variable Investment, which equals 1 if a bank has invested in at least one fintech and 0 if the alliance is characterized by a product-related collaboration. We use $\ln$ (Bank Total Assets) and the variable Fintech Employees, indicating the fintech's number of employees, as respective measures of bank and fintech size, which serve as our main explanatory variables. In addition to the control variables from Hypothesis 1, we include other variables to control for fintech characteristics: Fintech Front-End Solution, which is a dummy variable equal to 1 if a fintech offers front-end 
Fig. 1 Emergence of bankfintech alliances by country and year. The sample includes 500 fintechs from 27 countries collected from 2007 to 2017. The figure shows the cumulative number of alliances in each year, grouped by the banks' home country

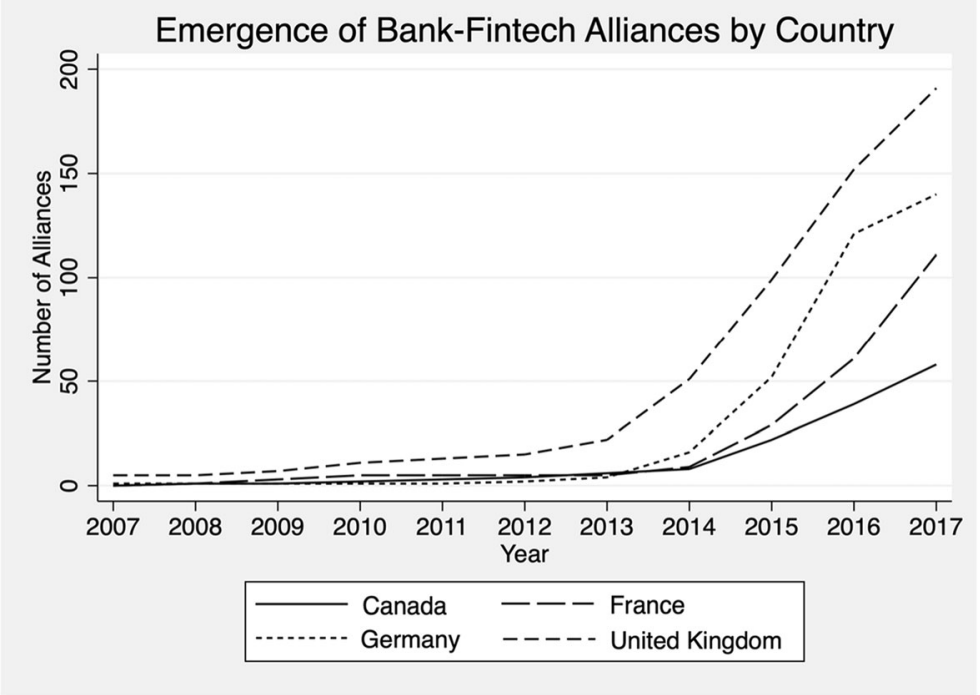

solutions and 0 if it offers back-end solutions; Fintech Headquarter, which is a dummy variable equal to 1 if the fintech operates in the same country as the partnering bank; Fintech Number of Patents, which counts the number of patents the fintech had previously registered; and Fintech Age, which accounts for the years since the fintech's founding. Table 1 provides detailed definitions of all variables and their sources.

\subsection{Methods}

To test Hypothesis 1, we estimate probit panel regressions. We follow Peng et al. (2017) and also include bank, country, and year fixed-effects to minimize the potential bias stemming from differences in, for example, national regulation or general technological trends that occur over time. Considering that many fintechs, such as Alipay or PayPal, are established firms and thus might act differently, we run a subsample analysis that excludes fintechs with more than 1000 employees or that were established at least 10 years before the bank-fintech alliance. Furthermore, we include our two main explanatory variables Digital Strategy and $C D O$ interchangeably in the same regressions because they are strongly correlated $(\rho=0.29)$ and potentially suffer from multicollinearity. Moreover, they constitute two alternative proxies for the same factor-a bank's strategic orientation in terms of digitalization. In our baseline specification, we estimate the following panel probit model, where $\operatorname{Pr}\left(\right.$ Alliance $\left._{i t}=1\right)$ is the probability that a bank $i$ has at least one alliance with a fintech in year $t$ :

$\operatorname{Pr}\left(\right.$ Alliance $\left._{i t}=1\right)=$

$F\left(\right.$ Digital Strategy $_{i t} /$ CDO $_{i t}+$ Bank is listed $_{i}+$ Digital Bank $_{i}+$ Universal Bank $_{i}+$ Bank HQ Country of Interest $_{i}+\ln \left({\left.\text { Bank } \text { Age }_{i t}\right)}+\right.$ Year $_{t}+$ Country $\left._{i}\right)$.

To test whether the bank's digital strategy or $\mathrm{CDO}$ is correlated with the number of bankfintech alliances, we estimate a count data model using the Number of New Alliances as the dependent variable. Because the dependent variable is a count variable and its unconditional variance suffers from overdispersion, we estimate a negative binomial panel regression. The baseline equation is 
Table 1 Definitions of variables included in the regression models

\begin{tabular}{|c|c|}
\hline Variable name & Definition \\
\hline \multicolumn{2}{|l|}{ Dependent variables } \\
\hline Alliance $(\mathrm{d})$ & $\begin{array}{l}\text { Binary variable equal to } 1 \text { if the bank engaged in at least one alliance with a fintech and } 0 \text { otherwise. We define } \\
\text { alliance as any type of contract- or investment-based interaction between a bank and fintech with the purpose } \\
\text { of collaborating. From the year the bank first announced an alliance, we presume that the bank continued with } \\
\text { this strategy and coded the variable accordingly. Source: Bank websites, Factiva, Google, Thomson Reuters } \\
\text { M\&A Database. }\end{array}$ \\
\hline $\begin{array}{l}\text { Number of new } \\
\text { alliances }\end{array}$ & Number of fintech alliances for a given bank and year. \\
\hline Investment $(\mathrm{d})$ & $\begin{array}{l}\text { Binary variable equal to } 1 \text { if a bank acquired at least a minority stake in a fintech and equal to } 0 \text { if the alliance is } \\
\text { characterized by a product-related collaboration. Other forms of alliances are excluded for this variable. } \\
\text { Source: Bank websites, Crunchbase, Factiva, fintech websites, Google, Thomson Reuters M\&A Database. }\end{array}$ \\
\hline $\mathrm{CAR}(-\mathrm{X} ;+\mathrm{Y})$ & $\begin{array}{l}\text { The cumulative abnormal return for the event window }(-\mathrm{X} ;+\mathrm{Y}) \text {. Event date } 0 \text { is the date of the first public } \\
\text { announcement of the alliance. In the analysis, we specify different windows. Source: Thomson Reuters } \\
\text { Datastream and own calculations. }\end{array}$ \\
\hline \multicolumn{2}{|l|}{ Bank characteristics } \\
\hline Bank listed (d) & Binary variable equal to 1 if the bank is publicly listed in a given year and 0 otherwise. Source: OnVista. \\
\hline Bank headquarter (d) & $\begin{array}{l}\text { Binary variable equal to } 1 \text { if the bank is located in the same country as the headquarters of the bank and } 0 \\
\text { otherwise. Source: Crunchbase, Fitch connect, fintech websites. }\end{array}$ \\
\hline Bank loan-to-asset ratio & Ratio of a bank's total loan outstanding to its total assets. Source: Fitch connect. \\
\hline Bank ROAA & Ratio of a bank's return to its average assets. Source: Fitch connect. \\
\hline $\mathrm{CDO}(\mathrm{d})$ & $\begin{array}{l}\text { Binary variable equal to } 1 \text { if the bank employs a CDO in the year of interest and } 0 \text { otherwise. Source: Annual } \\
\text { reports, LinkedIn, Bank website. }\end{array}$ \\
\hline Digital bank (d) & $\begin{array}{l}\text { Binary variable equal to } 1 \text { if the bank is a direct bank without a branch network, offering only remote services via } \\
\text { online and telephone banking, and } 0 \text { otherwise. Source: Bank websites. }\end{array}$ \\
\hline Digital strategy $(\mathrm{d})$ & $\begin{array}{l}\text { Binary variable equal to } 1 \text { if the bank announced a clear digital strategy, which entails a roadmap of concrete } \\
\text { measures and actions in their its report. From the year the bank first announced a digital strategy, we presume } \\
\text { that the bank continued with this strategy and coded the variable accordingly. Source: Annual reports. }\end{array}$ \\
\hline $\ln ($ bank age $)$ & Natural logarithm of the bank's age in years. Source: Fitch connect. \\
\hline $\ln$ (bank total assets) & Natural logarithm of the bank's total assets. Source: Fitch connect. \\
\hline Universal bank (d) & $\begin{array}{l}\text { Binary variable equal to } 1 \text { if the bank participates in various banking services and } 0 \text { otherwise. Source: Bank } \\
\text { websites. }\end{array}$ \\
\hline \multicolumn{2}{|l|}{ Fintech characteristics } \\
\hline $\begin{array}{l}\text { Fintech employees } \\
\quad \text { (rank) }\end{array}$ & $\begin{array}{l}\text { Range of the fintech's employees. Categories: } 1-10,11-50,51-100,101-1000,>1000 \text {. Source: Crunchbase, } \\
\text { fintech website, LinkedIn. }\end{array}$ \\
\hline Fintech age & Age of the fintech in years in the respective year. Source: Crunchbase, fintech website, LinkedIn. \\
\hline $\begin{array}{l}\text { Fintech front-end solu- } \\
\text { tion (d) }\end{array}$ & $\begin{array}{l}\text { Binary variable equal to } 1 \text { if the fintech offers front-end solutions and } 0 \text { otherwise. Source: Crunchbase, fintech } \\
\text { website, LinkedIn. }\end{array}$ \\
\hline $\begin{array}{l}\text { Fintech headquarters } \\
\text { (d) }\end{array}$ & $\begin{array}{l}\text { Binary variable equal to } 1 \text { if the fintech is located in the same country as the bank's headquarters and } 0 \text { otherwise. } \\
\text { Source: Crunchbase, fintech website, LinkedIn. }\end{array}$ \\
\hline $\begin{array}{l}\text { Fintech number of } \\
\text { patents }\end{array}$ & Total number of patents held by the fintech in December 2017. Source: PATSTAT. \\
\hline
\end{tabular}

(d) indicates a dummy variable

$\operatorname{Pr}\left(y_{i 1}, y_{i 2}, \ldots, y_{i T}\right)=F\left(\right.$ Digital Strategy $_{i t} /$ CDOO $_{i t}+$ Bank is listed $_{i}+$ Digital Bank $_{i}+$ Universal Bank $_{i}+$ Bank HQ Country of Interest $_{i}+\ln \left(\right.$ Bank Age $\left._{i t}\right)+$ Year $_{t}+$ Country $\left._{i}\right)$, 
where $y_{i t}$ refers to the dependent variable Number of New Alliances. If a Hausman test indicates that a model with random-effects is an inconsistent estimator, we adopt the fixed-effects model. Otherwise, we rely on random-effects in the respective regressions.

To test Hypotheses 2a and 2b, we estimate standard probit regressions. The baseline equation is

$$
\begin{aligned}
& \operatorname{Pr}\left(\text { Financial Investment }_{i}=1\right)= \\
& \begin{array}{l}
F\left(\text { In }_{\text {Bank Total Assets }}\right)+\text { Fintech Employees }_{i}+\text { Digital Strategy }_{i} / \text { CDO }_{i} \\
\left.\quad+\text { Bank is listed }_{i}+\text { Digital Bank }_{i}+\text { Universal Bank }_{i}+\text { Bank HQ Country of Interest }_{i}+\ln \left(\text { Bank Age }_{i}\right)+\text { Country }_{i}\right) .
\end{array}
\end{aligned}
$$

In line with prior studies that have investigated how strategic alliances and joint-venture announcements affect stock prices (Amici et al. 2013; Chiou and White 2005), we rely on cumulative abnormal returns (CARs) to assess changes in the market valuation of banks after the announcement to establish an alliance with a fintech. We use the market model to calculate abnormal returns (following Brown and Warner 1980, 1985), which is widely used in event studies. To be included in the sample, we required that the date of the first public announcement about the bank-fintech alliance could be uniquely identified and stock price data were available to calculate the returns for a minimum of 46 days before the first press announcement. We manually searched for the International Securities Identification Number of the banks in our sample on the websites of various retail brokers and financial data providers such as OnVista and Finanztreff. We then extracted stock prices from Thomson Reuters Datastream. After we excluded non-listed firms, 140 alliances with 30 publicly listed banks remained for the period from 2007 to 2017. More specifically, we identified 28 announcements of fintech alliances from Canada (from eight listed banks), 23 from France (from six listed banks), 40 from Germany (from five listed banks), and 49 from the United Kingdom (from 11 listed banks).

As a benchmark stock portfolio for the country where the respective bank had its headquarters, we used the MSCI index, which measures the performance of the large and mid-cap segments of each market (MSCI 2018). We estimated the parameters of the market model over a 200-trading-day window, ending 20 days before the event day to avoid bias in the parameter estimations due to incidents surrounding the event date (Brown and Warner 1985).

\section{Empirical results}

\subsection{Descriptive statistics}

Table 2 provides summary statistics for our panel dataset of the 100 largest banks in Canada, France, Germany, and the United Kingdom. During the sample period, $39 \%$ of all banks engaged in some form of alliance. The share of banks following a digital strategy is $57 \%$, while just $10 \%$ of the banks employ a CDO. ${ }^{5}$ Overall, $15 \%$ of the banks in our sample are publicly listed, $7 \%$ are digital banks, and $40 \%$ are universal banks. Figure 2 shows the distribution of fintech alliances by bank size. The 10 largest banks in each country account for slightly more than half the alliances between banks and fintechs in our sample.

Table 3 provides summary statistics for the alliance sample covering 500 bank-fintech alliances. We find that $33 \%$ of the 154 banks partnering with fintechs made at least a minority investment. ${ }^{6}$ Considering only banks that collaborate with fintechs, we find that $76 \%$ have a digital strategy and $15 \%$ employ a CDO. In the alliance sample, $23 \%$ of the banks are publicly listed, $10 \%$ are digital banks, and $44 \%$ are universal banks.

Figure 3 provides an overview of the segments in which fintechs that formed a bank-fintech alliance operate and shows that many fintechs operate in the payment services sector. While fintechs

\footnotetext{
${ }^{5}$ These figures do not correspond to those in Table 2, as they are based on the bank level and the table reports statistics of our panel dataset, in which banks are represented for several years.

${ }^{6}$ These figures do not correspond to those in Table 3, as some banks have engaged in multiple alliances and the table reports statistics of our alliance dataset.
} 
Table 2 Summary statistics of panel data for bank-year observations by the 100 largest banks each in Canada, France, Germany, and the United Kingdom from 2007 to 2017

\begin{tabular}{lllllll}
\hline Variable & Mean & SD (overall) & SD (between) & SD (within) & Number of banks & Number of observations \\
\hline Dependent variables & & & & & & \\
$\quad$ Alliance (d) & 0.12 & 0.32 & 0.20 & 0.25 & 400 & 4400 \\
$\quad$ Number of new alliances & 0.11 & 0.72 & 0.35 & 0.63 & 400 & 4400 \\
Explanatory variables & & & & & 3394 \\
Digital strategy (d) & 0.21 & 0.41 & 0.25 & 0.34 & 327 & 3871 \\
CDO (d) & 0.03 & 0.16 & 0.10 & 0.13 & 353 & 4400 \\
Bank listed (d) & 0.15 & 0.35 & 0.35 & 0.00 & 400 & 4400 \\
Digital bank (d) & 0.07 & 0.26 & 0.26 & 0.00 & 400 & 4400 \\
Universal bank (d) & 0.40 & 0.49 & 0.49 & 0.00 & 400 & 4378 \\
Bank headquarter (d) & 0.82 & 0.38 & 0.38 & 0.00 & 398 & 4081 \\
ln(bank age) & 3.83 & 0.96 & 0.96 & 0.00 & 371 & 3345 \\
ln(bank total assets) & 16.65 & 2.41 & 2.26 & 1.06 & 375 & 3211 \\
Bank loan-to-asset ratio & 0.57 & 0.26 & 0.26 & 0.08 & 366 & 3191 \\
Bank ROAA & 0.01 & 0.04 & 0.04 & 0.03 & 374 & \\
\hline
\end{tabular}

(d) indicates a dummy variable

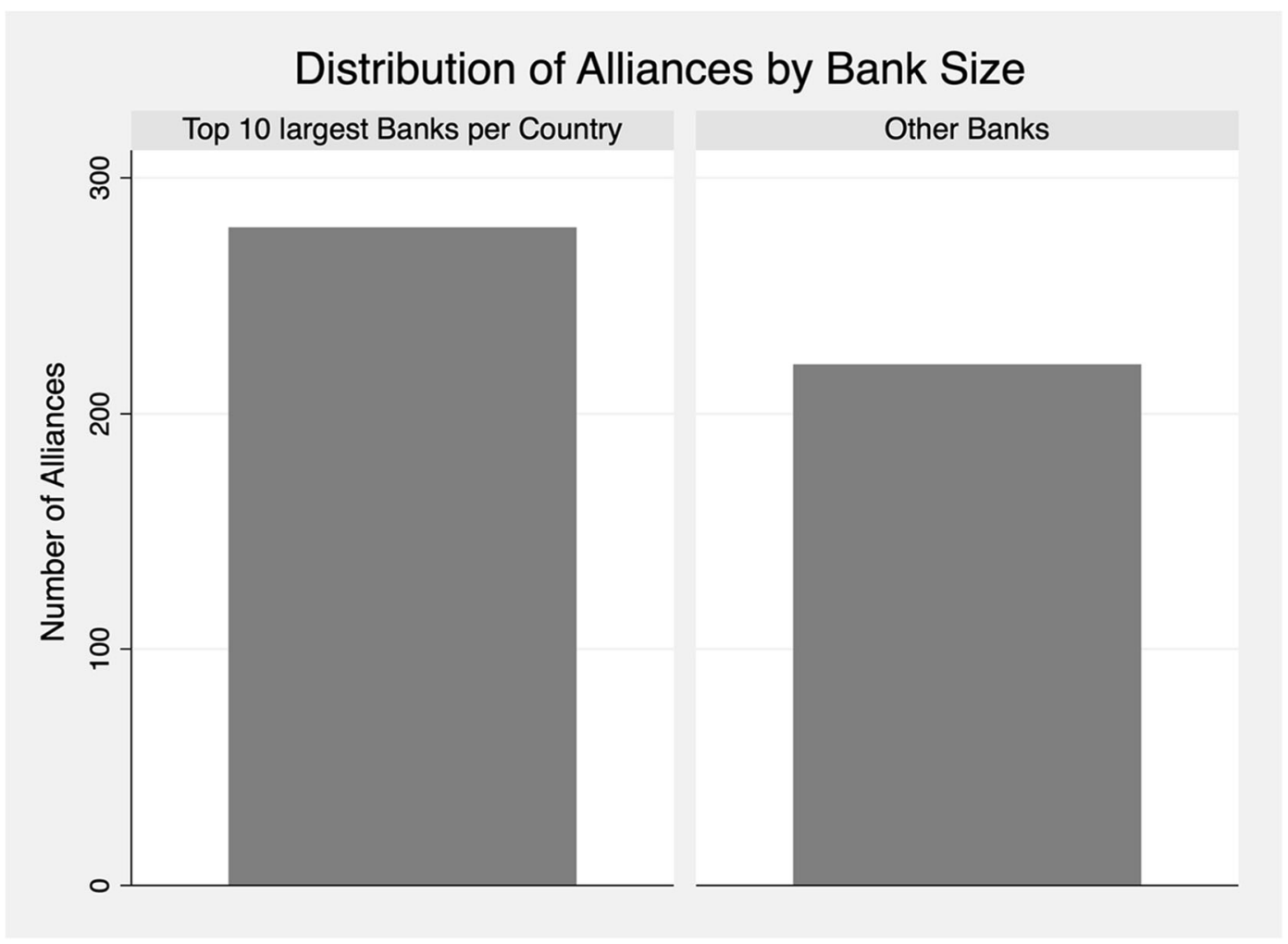

Fig. 2 Distribution of alliances by bank size. The figure shows the cumulative number of alliances for the top 10 largest banks in Canada, France, Germany, and the United Kingdom, compared with the remaining 460 banks 
Table 3 Summary statistics of deal-level data for alliances identified between banks and fintechs in Canada, France, Germany, and the United Kingdom from 2007 to 2017

\begin{tabular}{|c|c|c|c|c|c|c|}
\hline Variable & \# Obs. & Mean & Median & Std. Dev. & Minimum & Maximum \\
\hline \multicolumn{7}{|l|}{ Dependent variables } \\
\hline Investment (d) & 455 & 0.44 & 0 & 0.50 & 0 & 1 \\
\hline \multicolumn{7}{|l|}{ Explanatory variables } \\
\hline Digital strategy (d) & 470 & 0.86 & 1 & 0.35 & 0 & 1 \\
\hline $\mathrm{CDO}(\mathrm{d})$ & 489 & 0.23 & 0 & 0.42 & 0 & 1 \\
\hline Fintech employees (rank) & 462 & 2.40 & 2 & 1.19 & 1 & 5 \\
\hline $\ln$ (bank total assets) & 362 & 18.99 & 19.79 & 2.26 & 12.53 & 22.73 \\
\hline Bank listed (d) & 500 & 0.56 & 1 & 0.50 & 0 & 1 \\
\hline Digital bank (d) & 500 & 0.11 & 0 & 0.31 & 0 & 1 \\
\hline Universal bank (d) & 500 & 0.67 & 1 & 0.47 & 0 & 1 \\
\hline Bank headquarter (d) & 500 & 0.87 & 1 & 0.34 & 0 & 1 \\
\hline $\ln ($ bank age $)$ & 498 & 4.08 & 4.14 & 0.93 & 1.10 & 5.86 \\
\hline Bank ROAA & 460 & 0.00 & 0 & 0.01 & -0.07 & 0.04 \\
\hline Fintech front-end solution & 463 & 0.71 & 1 & 0.46 & 0 & 1 \\
\hline Fintech headquarter (d) & 493 & 0.65 & 1 & 0.48 & 0 & 1 \\
\hline Fintech number of patents & 500 & 1.67 & 0 & 8.49 & 0 & 158 \\
\hline Fintech age & 456 & 5.67 & 4 & 6.41 & 0 & 45 \\
\hline
\end{tabular}

(d) indicates a dummy variable

generally engage most often in financing (Haddad and Hornuf 2019), this is not part of their core business in our sample, which includes only fintechs that formed an alliance with banks. In comparison with Canada, France, and Germany, a relatively large number of UK fintechs provide bank-level software, such as digital tools for customer relationship management. Furthermore, we could not assign many UK fintechs to one of the predefined segments, indicating that they either offer more diversified services or operate in niche segments.

Figure 4 shows the most common types of bankfintech alliances. We classified them into four categories: minority investment, majority investment, product-related collaboration, and other forms of alliances. We find that minority investments and product-related collaborations are the two most common alliance types in all four countries, which suggests that comparatively loose forms of alliances are preferred. We find a relatively high number of majority investments in France, even though they are still smaller than alliances in the form of minority investments and product-related collaborations.

\subsection{Regression results}

\subsubsection{Establishing alliances}

In Table 4, we examine whether a Digital Strategy or the employment of a $C D O$ is in line with bank-fintech alliances. We find that the coefficients of Digital Strategy for regressions (1) and (3) are consistently positive and significant, suggesting that having a strategic focus on digitalization increases the probability of forming an alliance with a fintech by $6 \%$ to $8 \%$. The probability of finding at least one bank-fintech alliance is $10 \%$ higher if a bank employs a $C D O$. Thus, our results for Digital Strategy and CDO provide support for Hypothesis 1. Moreover, we find significant, positive coefficients for Bank Listed in models (2) and (4) and for $\ln$ (Bank Total Assets) in model (3), suggesting that the sheer size of a bank is associated with more bank-fintech alliances.

As a robustness check and as a way to exclude large, established fintechs, we ran the same analysis for the subsample of fintechs with fewer than 1000 employees or which were less than 10 years old at the time of forming the alliance. We find that no bank in our sample began an alliance with a large fintech without starting at 


\section{Fintech Segments by Country}

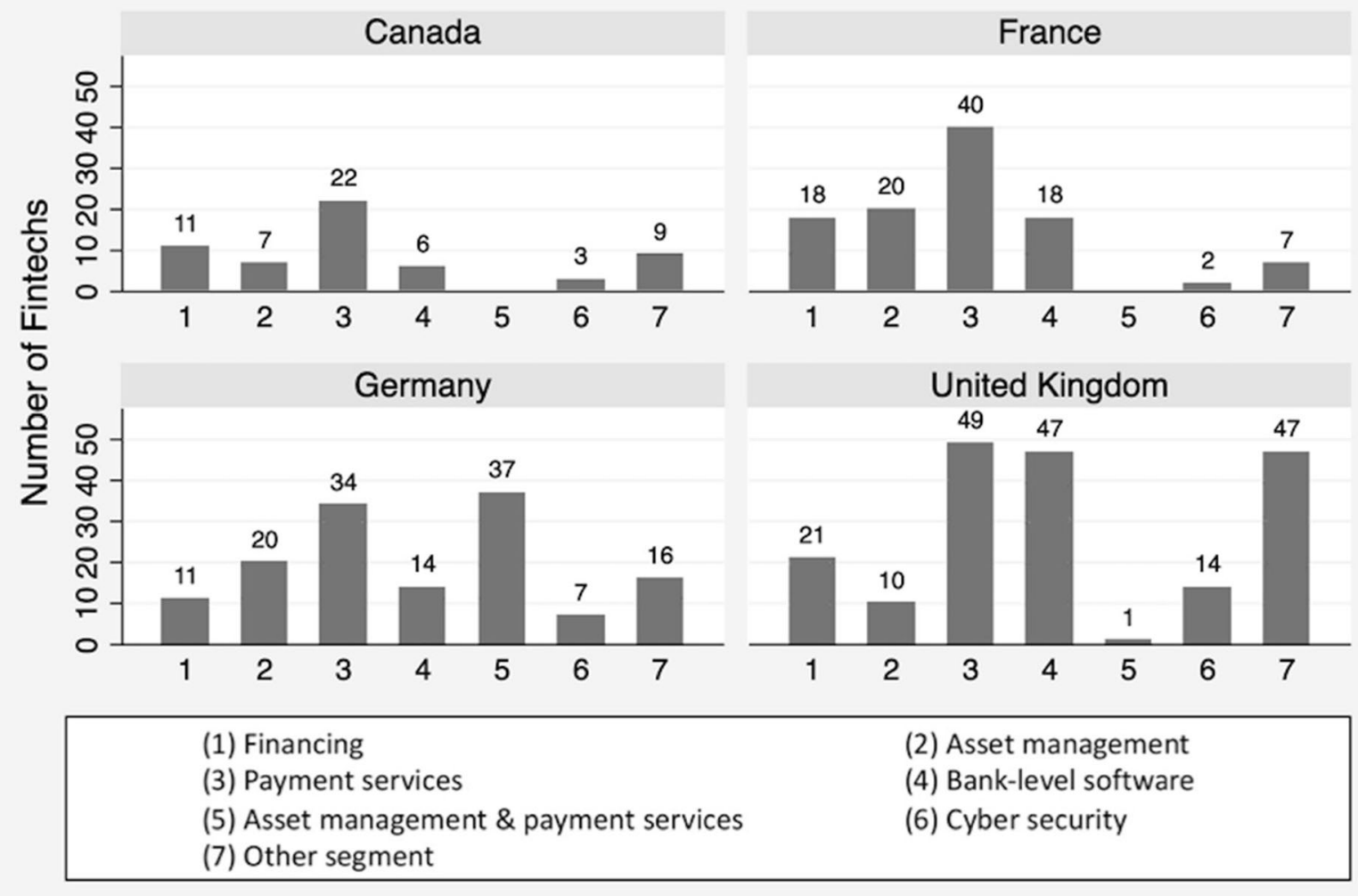

Fig. 3 Frequency of occurrence of bank alliances with fintechs by segment and country. The sample includes 492 identified fintech segments. The bars represent the number of fintechs in each segment and grouped by the banks' home country

least another one with a smaller fintech in the same year. Thus, when measuring the dependent variable as a dummy, we obtain exactly the same dataset both with and without the large, established fintechs (this is different for the number of alliances as well as in the crosssectional analysis).

Next, we investigate whether Digital Strategy or $C D O$ is also correlated with the number of fintechs with which a bank collaborates. Table 5 reports the results of the negative binominal regressions. We report incident rate ratios, which can be interpreted as multiplicative effects or semi-elasticities. The coefficients of Digital Strategy in models (1), (3), (5), and (7) are positive and statistically significant at the $0.1 \%$ level. In economic terms, banks with a digital strategy have three to four times more alliances with fintechs than banks without a digital strategy. The coefficient of $C D O$ is positive and statistically significant in all models that include this variable. Banks employing a CDO have two to three times more alliances with fintechs than banks without a CDO. These findings are robust to the exclusion of large fintechs in the sample (regressions (5)-(8)). Overall, our findings indicate that a bank's strategic orientation is positively correlated with the number of alliances with fintechs. The coefficients of Bank Listed and $\ln$ (Bank Total Assets) are statistically significant and have a positive effect in all the regressions. Accordingly, large and listed banks interact with more fintechs than small and private banks.

\subsubsection{Types of alliances}

To test Hypotheses $2 \mathrm{a}$ and $2 \mathrm{~b}$, we construct a binary dependent variable that classifies the two broad types of alliances, which we denote as Investment. This allows us to further investigate what motivates the type of alliance while integrating additional explanatory variables measuring various fintech characteristics. Because some 


\section{Forms of Alliances by Country}

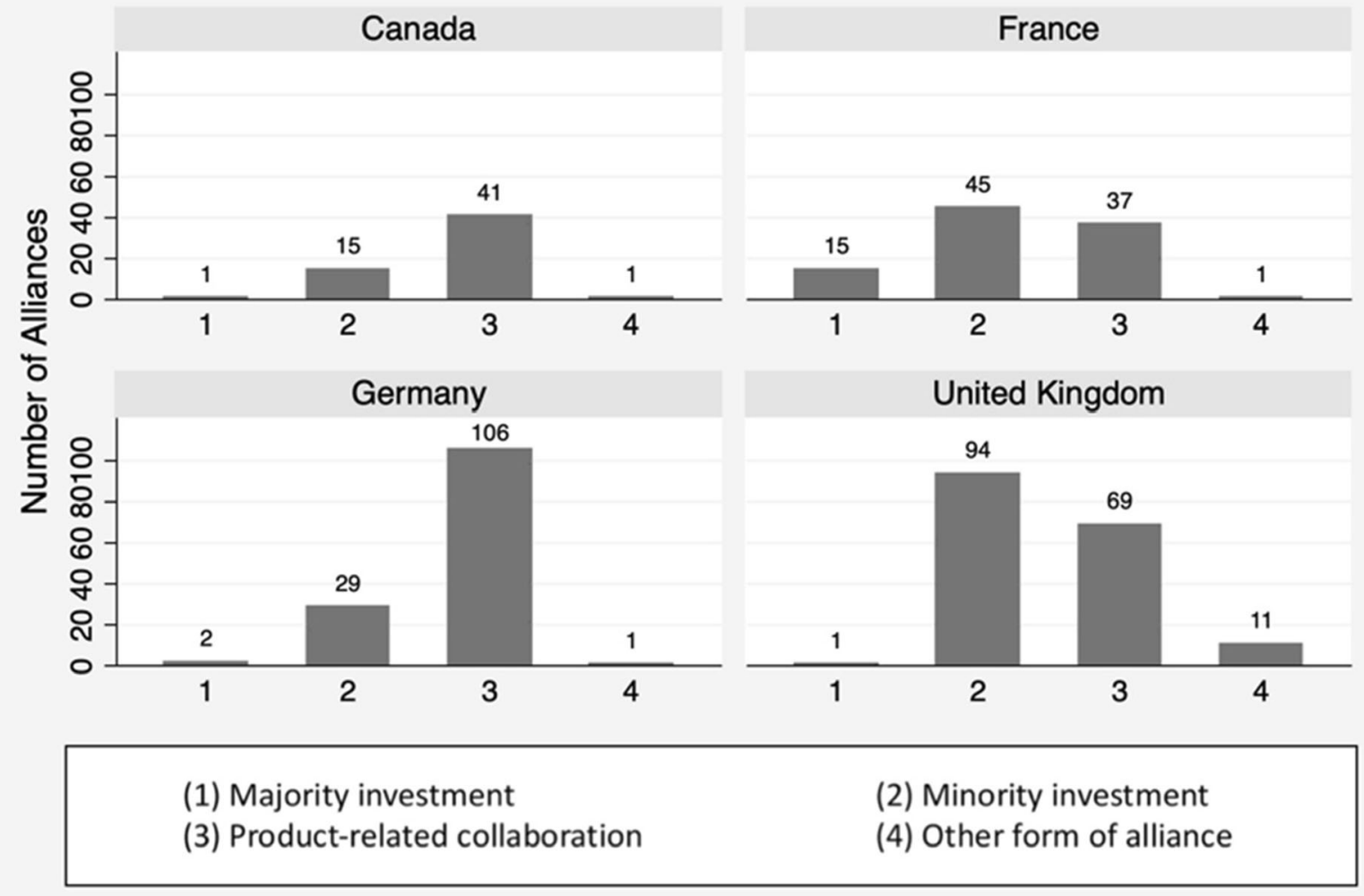

Fig. 4 Frequency of occurrence of interacting fintechs by form and country. The sample includes 469 interacting fintechs from 28 countries collected from 2007 to 2017 . The bars represent the frequency of the different arrangements of interaction with banks in Canada, France, Germany, and the United Kingdom

only considering fintechs with fewer than $1000 \mathrm{em}-$ ployees. The coefficients of $\ln$ (Bank Total Assets) are positive and statistically significant at the $1 \%$ level in regressions (1) and (2), indicating that, when accounting for both small and large fintechs, large banks are more likely to invest in fintechs, which is in line with Hypothesis 2a. Again, the effect diminishes when we exclude large fintechs, suggesting that the bank's size does not play a role when only small fintech startups are considered. Furthermore, the coefficients of Universal Bank are negative and statistically significant at the 5\% level in all regressions. This suggests that specialized banks that focus on particular industries or business segments are more likely to invest in fintechs, while universal banks seem to benefit more from productrelated collaborations.

To examine whether stock price reactions occurred after an alliance was publicly announced, we calculate 
Table 4 Panel data analysis for the dummy variables Digital Strategy, CDO, and Alliance

\begin{tabular}{|c|c|c|c|c|}
\hline & \multicolumn{4}{|l|}{ Full sample } \\
\hline & \multicolumn{4}{|c|}{ Dependent variable: alliance $(\mathrm{d})$} \\
\hline \multicolumn{5}{|l|}{ Explanatory variables } \\
\hline Digital strategy (d) & $\begin{array}{l}0.060 * * * \\
(0.018)\end{array}$ & & $\begin{array}{l}0.077 * * * \\
(0.021)\end{array}$ & \\
\hline $\mathrm{CDO}(\mathrm{d})$ & & $\begin{array}{l}0.095 * \\
(0.043)\end{array}$ & & $\begin{array}{l}0.072 \\
(0.042)\end{array}$ \\
\hline Bank listed (d) & $\begin{array}{l}0.062 \\
(0.048)\end{array}$ & $\begin{array}{l}0.099 * * \\
(0.038)\end{array}$ & $\begin{array}{l}0.054 \\
(0.045)\end{array}$ & $\begin{array}{l}0.090 * \\
(0.040)\end{array}$ \\
\hline Digital bank (d) & $\begin{array}{l}0.003 \\
(0.044)\end{array}$ & $\begin{array}{l}0.044 \\
(0.042)\end{array}$ & $\begin{array}{l}0.078 \\
(0.050)\end{array}$ & $\begin{array}{l}0.077 \\
(0.072)\end{array}$ \\
\hline Universal bank (d) & $\begin{array}{l}0.028 \\
(0.020)\end{array}$ & $\begin{array}{l}0.036 \\
(0.025)\end{array}$ & $\begin{array}{l}0.040 * \\
(0.021)\end{array}$ & $\begin{array}{l}0.035 \\
(0.020)\end{array}$ \\
\hline Bank headquarter (d) & $\begin{array}{l}0.001 \\
(0.034)\end{array}$ & $\begin{array}{l}0.011 \\
(0.025)\end{array}$ & $\begin{array}{l}0.006 \\
(0.046)\end{array}$ & $\begin{array}{l}0.025 \\
(0.032)\end{array}$ \\
\hline $\ln ($ bank age $)$ & $\begin{array}{l}0.011 \\
(0.013)\end{array}$ & $\begin{array}{l}0.013 \\
(0.013)\end{array}$ & $\begin{array}{l}0.018 \\
(0.013)\end{array}$ & $\begin{array}{l}0.027 * * \\
(0.010)\end{array}$ \\
\hline $\ln$ (bank total assets) & & & $\begin{array}{l}0.013 * * * \\
(0.004)\end{array}$ & $\begin{array}{l}0.009 \\
(0.005)\end{array}$ \\
\hline Bank loan-to-asset ratio & & & $\begin{array}{l}-0.033 \\
(0.044)\end{array}$ & $\begin{array}{l}0.003 \\
(0.039)\end{array}$ \\
\hline Bank ROAA & & & $\begin{array}{l}-0.145 \\
(0.390)\end{array}$ & $\begin{array}{c}-0.318 \\
(0.310)\end{array}$ \\
\hline Year dummies & Yes & Yes & Yes & Yes \\
\hline Country dummies & Yes & Yes & Yes & Yes \\
\hline n (Obs.) & 3344 & 3816 & 2421 & 2743 \\
\hline $\mathrm{N}$ (banks) & 322 & 348 & 297 & 318 \\
\hline Wald $\chi^{2}$ & 37.77 & 77.91 & 139.71 & 92.21 \\
\hline Prob $>\chi^{2}$ & 0.000 & 0.000 & 0.000 & 0.000 \\
\hline
\end{tabular}

The table presents the results of random-effects probit regression modeling the probability that at least one interaction between bank $i$ and a fintech occurs in year $t$ (dependent variable $=1$ ) or not (dependent variable $=0$ ), based on the full sample. The coefficients show the average marginal effects with bootstrapped standard errors in parentheses. All variables are defined in Table $1 . *$ denotes significance at the 5\% level, $* *$ at the $1 \%$ level, and $* * *$ at the $0.1 \%$ level. (d) indicates a dummy variable

cumulative average abnormal returns (CAARs) for different event windows. We find that all short-term windows have a negative impact and that the event windows with $(-1 ; 0)$ and $(-1 ;+1)$ are statistically significant at the $5 \%$ level. Thus, at least in the short run, investors perceive alliances with fintechs as having, on average, a negative effect on firm value; thus, Hypothesis 3 is rejected. We might interpret this result as indicating that markets believe banks should develop new digital services themselves instead. However, Table 7 reveals that the CAARs are not negative for all banks and that, in some cases, investors value the public announcement of an alliance. We run ordinary least square regressions not only on our financial performance measure, CARs, for the short event windows $(-1 ; 0),(0 ;+1)$, and $(-1 ;+1)$, as Amici et al. (2013) and Chiou and White (2005) suggest, but also for the longer event window $(0 ;+$ $100)$ to account for potential momentum effects.

In unreported regressions, we find that Digital Strategy is positive and statistically significant for 
Table 5 Panel data analysis for the variables Digital Strategy, CDO, and Number of Partnerships

\begin{tabular}{|c|c|c|c|c|c|c|c|c|}
\hline & \multicolumn{4}{|c|}{ Full sample } & \multicolumn{4}{|c|}{ Excluding large fintechs } \\
\hline & Dependent & ariable: num & er of allianc & & & & & \\
\hline \multicolumn{9}{|l|}{ Explanatory variables } \\
\hline Digital strategy (d) & $\begin{array}{l}4.097 * * * \\
(1.074)\end{array}$ & & $\begin{array}{l}3.133 * * * \\
(0.839)\end{array}$ & & $\begin{array}{l}4.791 * * * \\
(1.485)\end{array}$ & & $\begin{array}{l}3.555^{* * * *} \\
(1.029)\end{array}$ & \\
\hline $\mathrm{CDO}(\mathrm{d})$ & & $\begin{array}{l}2.721 * * * \\
(0.673)\end{array}$ & & $\begin{array}{l}1.945 * * \\
(0.416)\end{array}$ & & $\begin{array}{l}2.815 * * * \\
(0.845)\end{array}$ & & $\begin{array}{l}1.810^{*} \\
(0.466)\end{array}$ \\
\hline Bank listed (d) & $\begin{array}{l}2.679 * * * \\
(0.554)\end{array}$ & $\begin{array}{l}4.061 * * * \\
(1.018)\end{array}$ & $\begin{array}{l}1.913 * * \\
(0.481)\end{array}$ & $\begin{array}{l}2.703 * * * \\
(0.748)\end{array}$ & $\begin{array}{l}3.529 * * * \\
(0.942)\end{array}$ & $\begin{array}{l}5.160 * * * \\
(1.550)\end{array}$ & $\begin{array}{l}1.953 * \\
(0.554)\end{array}$ & $\begin{array}{l}2.715^{* *} \\
(0.895)\end{array}$ \\
\hline Digital bank (d) & $\begin{array}{l}1.418 \\
(0.561)\end{array}$ & $\begin{array}{l}1.946 \\
(0.865)\end{array}$ & $\begin{array}{l}2.174 * * \\
(0.649)\end{array}$ & $\begin{array}{l}2.225 \\
(0.910)\end{array}$ & $\begin{array}{l}1.597 \\
(0.764)\end{array}$ & $\begin{array}{l}2.477 * \\
(1.015)\end{array}$ & $\begin{array}{l}2.019 \\
(0.792)\end{array}$ & $\begin{array}{l}2.295 * \\
(0.793)\end{array}$ \\
\hline Universal bank (d) & $\begin{array}{l}1.715 * \\
(0.382)\end{array}$ & $\begin{array}{l}1.719 * * \\
(0.348)\end{array}$ & $\begin{array}{l}1.534 \\
(0.360)\end{array}$ & $\begin{array}{l}1.506 \\
(0.327)\end{array}$ & $\begin{array}{l}1.663 * \\
(0.406)\end{array}$ & $\begin{array}{l}1.682 * \\
(0.393)\end{array}$ & $\begin{array}{l}1.445 \\
(0.352)\end{array}$ & $\begin{array}{l}1.397 \\
(0.466)\end{array}$ \\
\hline Bank headquarter (d) & $\begin{array}{l}0.876 \\
(0.265)\end{array}$ & $\begin{array}{l}1.003 \\
(0.333)\end{array}$ & $\begin{array}{l}0.814 \\
(0.239)\end{array}$ & $\begin{array}{l}0.944 \\
(0.372)\end{array}$ & $\begin{array}{l}0.739 \\
(0.281)\end{array}$ & $\begin{array}{l}0.967 \\
(0.326)\end{array}$ & $\begin{array}{l}0.761 \\
(0.225)\end{array}$ & $\begin{array}{l}0.996 \\
(0.364)\end{array}$ \\
\hline $\ln ($ bank age $)$ & $\begin{array}{l}1.112 \\
(0.116)\end{array}$ & $\begin{array}{l}0.171 \\
(0.093)\end{array}$ & $\begin{array}{l}1.144 \\
(0.116)\end{array}$ & $\begin{array}{l}1.213 \\
(0.127)\end{array}$ & $\begin{array}{l}1.183 \\
(0.142)\end{array}$ & $\begin{array}{l}1.253 * \\
(0.124)\end{array}$ & $\begin{array}{l}1.121 \\
(0.119)\end{array}$ & $\begin{array}{l}1.213 \\
(0.129)\end{array}$ \\
\hline $\ln$ (bank total assets) & & & $\begin{array}{l}1.283 * * * \\
(0.061)\end{array}$ & $\begin{array}{l}1.248 * * * \\
(0.056)\end{array}$ & & & $\begin{array}{l}1.357 * * * \\
(0.072)\end{array}$ & $\begin{array}{l}1.338 * * * \\
(0.071)\end{array}$ \\
\hline Bank loan-to-asset ratio & & & $\begin{array}{l}0.706 \\
(0.277)\end{array}$ & $\begin{array}{l}0.961 \\
(0.386)\end{array}$ & & & $\begin{array}{l}0.871 \\
(0.420)\end{array}$ & $\begin{array}{l}1.105 \\
(0.480)\end{array}$ \\
\hline Bank ROAA*100 & & & $\begin{array}{l}0.876^{* * *} \\
(0.044)\end{array}$ & $\begin{array}{l}0.876^{*} \\
(0.049)\end{array}$ & & & $\begin{array}{l}0.859 * * \\
(0.043)\end{array}$ & $\begin{array}{l}0.899 * \\
(0.046)\end{array}$ \\
\hline Year dummies & Yes & Yes & Yes & Yes & Yes & Yes & Yes & Yes \\
\hline Country dummies & Yes & Yes & Yes & Yes & Yes & Yes & Yes & Yes \\
\hline $\mathrm{n}(\mathrm{Obs})$. & 3344 & 3816 & 2421 & 2743 & 3344 & 3816 & 2421 & 2743 \\
\hline $\mathrm{N}$ (banks) & 322 & 348 & 297 & 318 & 322 & 348 & 297 & 318 \\
\hline Wald $\chi^{2}$ & 344.79 & 458.02 & 516.57 & 917.83 & 491.83 & 311.20 & 1501.03 & 1151.03 \\
\hline Prob $>\chi^{2}$ & 0.000 & 0.000 & 0.000 & 0.000 & 0.000 & 0.000 & 0.000 & 0.000 \\
\hline
\end{tabular}

The table presents the results of random-effects negative binominal regressions. The dependent variable represents the number of new alliances of bank $i$ in year $t$. We report incident-rate ratios with bootstrapped standard errors in parentheses. Models 1-4 use the full sample; models 5-8 exclude fintechs with more than 1000 employees or fintechs that were more than 10 years old at the time of the alliance. All variables are defined in Table 1. A Hausman test is used to identify whether fixed-effects or random-effects should be applied to each respective model. * denotes significance at the $5 \%$ level, $* *$ at the $1 \%$ level, and $* * *$ at the $0.1 \%$ level. (d) indicates a dummy variable

the $(0 ;+100)$ event windows. Moreover, digital banks benefit the most from a strategic alliance i.e., the variable Digital Bank is positive and statistically significant for most short-term event windows. Depending on the specification considered, the bank value increases by 2.5 to $3.2 \%$ after the digital bank announces a new alliance with a fintech. None of the other bank or fintech variables affect bank value when it comes to a fintech alliance.

\section{Discussion}

In this article, we examined the impact of digitalization in the banking industry by analyzing the bank characteristics that play a role in the alliances between banks and fintech startups. Moreover, we investigated the factors that are relevant for a bank to invest in a fintech rather than entering into a product-related collaboration. Finally, we tested whether announcing a new alliance affects banks' market value. 
Table 6 Cross-sectional regression results for investment versus product-related collaboration

\begin{tabular}{|c|c|c|c|c|}
\hline & \multicolumn{2}{|c|}{ Full sample } & \multicolumn{2}{|c|}{$\begin{array}{l}\text { Excluding large } \\
\text { fintechs }\end{array}$} \\
\hline & \multicolumn{4}{|c|}{ Dependent variable: investment (d) } \\
\hline \multicolumn{5}{|l|}{ Explanatory variables } \\
\hline $\begin{array}{l}\text { Digital strategy } \\
\text { (d) }\end{array}$ & $\begin{array}{l}-0.069 \\
(0.083)\end{array}$ & & $\begin{array}{l}-0.078 \\
(0.104)\end{array}$ & \\
\hline $\mathrm{CDO}(\mathrm{d})$ & & $\begin{array}{l}-0.082 \\
(0.118)\end{array}$ & & $\begin{array}{l}-0.113 \\
(0.122)\end{array}$ \\
\hline $\begin{array}{l}\text { Fintech } \\
\text { employees } \\
\text { (rank) }\end{array}$ & $\begin{array}{l}-0.098^{* * *} \\
(0.026)\end{array}$ & $\begin{array}{l}-0.095^{* * * *} \\
(0.026)\end{array}$ & $\begin{array}{l}-0.037 \\
(0.035)\end{array}$ & $\begin{array}{l}-0.034 \\
(0.036)\end{array}$ \\
\hline $\begin{array}{l}\ln \text { (bank total } \\
\text { assets) }\end{array}$ & $\begin{array}{l}0.057 * * \\
(0.019)\end{array}$ & $\begin{array}{l}0.050 * * \\
(0.018)\end{array}$ & $\begin{array}{l}0.048^{*} \\
(0.022)\end{array}$ & $\begin{array}{l}0.041 \\
(0.021)\end{array}$ \\
\hline Bank listed (d) & $\begin{array}{l}0.107 \\
(0.114)\end{array}$ & $\begin{array}{l}0.132 \\
(0.126)\end{array}$ & $\begin{array}{l}0.160 \\
(0.123)\end{array}$ & $\begin{array}{l}0.186 \\
(0.134)\end{array}$ \\
\hline Digital bank (d) & $\begin{array}{l}0.181 \\
(0.121)\end{array}$ & $\begin{array}{l}0.185 \\
(0.119)\end{array}$ & $\begin{array}{l}0.205 \\
(0.121)\end{array}$ & $\begin{array}{l}0.204 \\
(0.119)\end{array}$ \\
\hline $\begin{array}{l}\text { Universal bank } \\
\text { (d) }\end{array}$ & $\begin{array}{l}-0.157 * \\
(0.070)\end{array}$ & $\begin{array}{l}-0.137 * \\
(0.067)\end{array}$ & $\begin{array}{l}-0.204 * \\
(0.080)\end{array}$ & $\begin{array}{l}-0.176^{*} \\
(0.080)\end{array}$ \\
\hline $\begin{array}{l}\text { Bank headquarter } \\
\text { (d) }\end{array}$ & $\begin{array}{l}-0.051 \\
(0.076)\end{array}$ & $\begin{array}{l}-0.080 \\
(0.104)\end{array}$ & $\begin{array}{l}-0.003 \\
(0.073)\end{array}$ & $\begin{array}{l}-0.055 \\
(0.105)\end{array}$ \\
\hline $\ln$ (bank age) & $\begin{array}{l}0.010 \\
(0.044)\end{array}$ & $\begin{array}{l}0.004 \\
(0.041)\end{array}$ & $\begin{array}{l}0.022 \\
(0.046)\end{array}$ & $\begin{array}{l}0.014 \\
(0.043)\end{array}$ \\
\hline Bank ROAA & $\begin{array}{l}4.501 \\
(7.238)\end{array}$ & $\begin{array}{l}2.589 \\
(7.091)\end{array}$ & $\begin{array}{l}2.515 \\
(6.930)\end{array}$ & $\begin{array}{l}0.654 \\
(7.344)\end{array}$ \\
\hline $\begin{array}{l}\text { Fintech front-end } \\
\text { solution (d) }\end{array}$ & $\begin{array}{l}-0.032 \\
(0.054)\end{array}$ & $\begin{array}{l}-0.039 \\
(0.055)\end{array}$ & $\begin{array}{l}-0.034 \\
(0.060)\end{array}$ & $\begin{array}{l}-0.043 \\
(0.061)\end{array}$ \\
\hline $\begin{array}{l}\text { Fintech } \\
\text { headquarter (d) }\end{array}$ & $\begin{array}{l}-0.143^{* *} \\
(0.055)\end{array}$ & $\begin{array}{l}-0.138^{* *} \\
(0.053)\end{array}$ & $\begin{array}{l}-0.094 \\
(0.060)\end{array}$ & $\begin{array}{l}-0.084 \\
(0.059)\end{array}$ \\
\hline $\begin{array}{l}\text { Fintech number of } \\
\text { patents }\end{array}$ & $\begin{array}{l}0.001 \\
(0.005)\end{array}$ & $\begin{array}{l}-0.000 \\
(0.005)\end{array}$ & $\begin{array}{l}0.000 \\
(0.006)\end{array}$ & $\begin{array}{l}-0.001 \\
(0.005)\end{array}$ \\
\hline Fintech age & $\begin{array}{l}-0.005 \\
(0.004)\end{array}$ & $\begin{array}{l}-0.006 \\
(0.005)\end{array}$ & $\begin{array}{l}-0.021^{*} \\
(0.010)\end{array}$ & $\begin{array}{l}-0.022^{*} \\
(0.011)\end{array}$ \\
\hline Country dummies & Yes & Yes & Yes & Yes \\
\hline $\mathrm{N}$ (banks) & 331 & 346 & 282 & 295 \\
\hline Pseudo $R^{2}$ & 0.273 & 0.285 & 0.268 & 0.285 \\
\hline Wald $\chi^{2}$ & 51.362 & 58.935 & 57.687 & 58.797 \\
\hline Prob $>\chi^{2}$ & 0.000 & 0.000 & 0.000 & 0.000 \\
\hline
\end{tabular}

The table presents the results of a probit regression. The coefficients show the average marginal effects, and standard errors are clustered by banks (in parentheses). Models 1 and 2 use the full sample; models 3 and 4 exclude fintechs with more than 1000 employees or fintechs that were more than 10 years old at the time of the alliance. All variables are defined in Table 1. * denotes significance at the $5 \%$ level, $* *$ at the $1 \%$ level, and $* * *$ at the $0.1 \%$ level. (d) indicates a dummy variable
Using a hand-collected dataset covering the 100 largest banks in Canada, France, Germany, and the United Kingdom, we found that bank-fintech alliances have increased in the past decade and that the types of alliances are rather similar in all four countries. Thus, we provide empirical evidence that digitalization and new market players have indeed forced banks to make their corporate boundaries more open to market interactions (Kohtamäki et al. 2019). However, there is no apparent difference in the way banks interact with fintechs in market-based (Canada and the United Kingdom) and bank-based (France and Germany) financial systems. Alliances across the four countries examined are most often characterized by a product-related collaboration, which is a comparatively less institutionalized form of alliance that offers little or no control in the product and service development process of a fintech. This finding is consistent with the theoretical observation that financial innovations may by particularly difficult for a bank to contract and internalize through an acquisition (Brandl and Hornuf 2020; Scott et al. 2017; Teece 1986). From a managerial perspective, this raises the question whether banks should use this form of alliance to outsource their innovation activities and thereby become increasingly dependent on fintechs and other partners for ensuring digital transformation.

While prior research suggests that banks should benefit from voluntary cooperation and innovations developed by fintechs in ways different from the simple make-or-buy decision (Borah and Tellis 2014; Jacobides and Billinger 2006), the results from our event study indicate that at least for short-term event windows, financial markets find alliances with fintech value-reducing. A potential explanation for this is that in the future, banks might be reduced to innovation followers in the new financial ecosystem, with incumbent banks quickly losing their relevance. We also find that fintechs engaging in alliances operate in various segments across the four countries we investigate, with payment services being the most prevalent segment. Given that, overall, most fintechs operate in the financing segment (Haddad and Hornuf 2019), banks seem to benefit most from external technology in the realm of payment services.

Our findings confirm that the implementation of a digital strategy and the employment of a CDO by a bank are positively related to both the mere existence and the number of alliances with fintechs. We consider this indication that alliances with fintechs, the employment of a CDO, and the execution of a clear digital strategy 
Table 7 CAARs for bank-fintech alliances

\begin{tabular}{|c|c|c|c|c|c|c|}
\hline \multirow[b]{2}{*}{ Event window } & \multirow[b]{2}{*}{ CAAR (\%) } & \multirow{2}{*}{$\begin{array}{l}t \text { test } \\
t \text { statistic }\end{array}$} & \multicolumn{4}{|c|}{ Wilcoxon sign-rank } \\
\hline & & & $z$ statistic & Minimum $(\%)$ & Maximum (\%) & Percentage of positive CAR (\%) \\
\hline-1 to +1 & -0.52 & $-2.050 *$ & -1.82 & -7.25 & 6.10 & 43.69 \\
\hline-1 to 0 & -0.53 & $-2.475^{*}$ & $-2.538 *$ & -5.43 & 4.59 & 38.95 \\
\hline 0 to +1 & -0.18 & -0.823 & -0.928 & -5.81 & 6.03 & 44.25 \\
\hline-3 to +3 & -0.72 & -1.893 & -1.564 & -12.06 & 8.25 & 42.70 \\
\hline-5 to +5 & -0.25 & -0.353 & -0.021 & -9.50 & 7.64 & 52.74 \\
\hline-10 to +10 & -0.70 & -1.117 & 1.591 & -15.24 & 17.55 & 46.95 \\
\hline 0 to 100 & 2.89 & 1.506 & -1.082 & -40.94 & 38.78 & 58.16 \\
\hline $\mathrm{N}$ & 140 & & & & & \\
\hline
\end{tabular}

The table reports descriptive statistics of CARs for various event windows. The sample includes 140 alliances by 30 publicly listed banks for the 2007-2017 period. Daily abnormal returns are obtained using the market model with a 200-trading-day window, ending 20 days before the event day to avoid bias in the parameter's estimations due to changes in firm characteristics around the event date. * denotes significance at the $5 \%$ level, $* *$ at the $1 \%$ level, and $* * *$ at the $0.1 \%$ level

are part of the same overall corporate change strategy. All these strategic approaches may enable banks to be more permeable to the outside market, which is necessary to foster different forms of alliances and remain competitive (Borah and Tellis 2014; Jacobides and Billinger 2006; Kohtamäki et al. 2019). We further find that large, listed, and universal banks are more likely to establish alliances with at least one fintech than smaller, unlisted, and specialized banks. The bank's financial situation, as measured by the return on average assets, is a relevant predictor for explaining the number of alliances in which a bank becomes involved. That less profitable banks engage more frequently in alliances with fintechs indicate that these banks try to compensate for their own inefficiency and inability to innovate by engaging in alliances. Whether such a strategy will improve their performance, however, remains unclear.

Product-related collaborations can help banks broaden their service portfolio and use alternative distribution channels to reach new customers. Such a strategy appears particularly beneficial for banks that cannot develop new digital services themselves because of their IT legacy or organizational structure. As mentioned previously, regarding the market effect of publicly announced alliances, we find that announcements have a negative effect on a bank's value for short-term windows. While this finding does not indicate much about the ultimate profitability of bank-fintech alliances, it suggests that markets believe that banks should develop new digital services themselves rather than engaging in alliances with fintechs.
Our results further suggest that neither a digital strategy nor the employment of a $\mathrm{CDO}$ is more strongly connected with an investment than with product-related collaborations. Although this finding contradicts our hypothesis and previous research on board positions (Geiger and North 2006; Jiang and Li 2009), we assume that CDOs do not simply focus on acquiring fintechs but also increasingly work to develop digitalization expertise in-house. We find, however, that large banks are more likely to become financially engaged in fintech firms. Through a minority investment or a full acquisition in a fintech, banks can often obtain representation on the fintech's board of directors and thereby gain complete or partial control over it. Ensuring a strong and stable relationship in strategic alliances, which from the start are inherently instable, is often critical to their success, as otherwise internal organizational tensions may result in conflicts and ultimately lead to the dissolution of an alliance (Das and Teng 2000). Moreover, through an investment, banks cannot only orchestrate specific service developments that fit the overall corporate change strategy but also engineer services in a way that enables them to integrate these services best in their existing organizational structures and IT infrastructure. Large banks often set up incubator and accelerator programs to obtain financial stakes in fintech firms early on. We find that banks are also more likely to financially invest in smaller fintechs. 


\section{Conclusion}

\subsection{Practical and policy implications}

Our empirical analysis has implications for the development of theories regarding strategic alliances and digital servitization in the domain of financial services. The new permeability in the financial industry might be the result of a top down-process, in which the corporate board initiated a general corporate change strategy that resulted in a digital strategy and the employment of a CDO. Alternatively, customers might demand more digital services (e.g., mobile payment solutions, roboadvise applications), and if these are implemented in a decentralized manner through, for example, different divisions of a bank, a CDO might be necessary if these services become more widespread over time.

Our work also has practical implications for fintech entrepreneurs, banks, and policy makers. Entrepreneurs seeking funds, regulatory advice, or access to customers may find it worthwhile to engage in an alliance with a bank. The form of collaboration, however, may depend on what is most beneficial for both. In particular, our findings show that entrepreneurs in need of capital may be more successful approaching large banks, because they are more likely to invest in fintechs; by contrast, fintech entrepreneurs who want to stay independent but need to reach new customers may favor smaller and specialized banks, which are more likely to engage in product-related collaborations. More generally, banks with a clearly defined digital strategy or a CDO are most likely to be receptive to entrepreneurs' request to collaborate or for investment.

It is important for banks to acknowledge that there is an upward trend toward hiring a CDO, which may become increasingly important as digitalization spreads across the different segments of the financial industry. However, according to our analysis, most banks still have not recognized the need for a CDO. Hiring a $\mathrm{CDO}$ may become more urgent in the future as financial technologies become more mature and the need to engage in alliances becomes more pressing. Financial institutions and policy makers will need to define which competencies CDOs must have and how banks can successfully hire such professionals. Moreover, an increasing reliance on alliances also raises questions about the existing technological infrastructure of banks. To collaborate effectively with a fintech, banks may rely on traditional information networks such as SWIFT or need to develop new suitable application programming interfaces. This again raises the demand for professionals who have experience not only in financial products and services but also in the respective IT infrastructure.

Finally, our work offers practical implications for policy makers who want to foster an acceleration of the usage of digital technologies in the financial sector. Depending on how policy makers want to shape the financial ecosystem, adopting a restrictive granting practice for bank licenses limits growth opportunities of fintechs as independent entities, because many activities (e.g., taking deposits, extending loans) require such a license. The restrictive granting of bank licenses could thus lead to an ecosystem that is increasingly based on alliances. This, in turn, may affect the relative stability, profitability, and, thus, viability of incumbent banks, a development that should be closely monitored by supervisory authorities.

\subsection{Limitations and future research avenues}

Our analysis also has clear limitations and thus offers avenues for future research. First, we do not examine the duration of bank-fintech alliances. A preliminary analysis of 150 alliances in our sample indicates that $17 \%$ ended by 2020 . A survey among banks and fintechs, as well as a systematic search on Factiva, showed that alliances were terminated mostly by banks because the banks developed their own technical solutions, the fintechs were sold to a competitor or went insolvent, or the contract or accelerator program came to an end. Future research could investigate what determines the success of bank-fintech alliances and whether the strategic engineering of digital services can be a successful strategy for incumbent players in the financial industry. Although Lerner et al. (2015) find that the quality of financial patents and financial innovations is often low, bank-fintech alliances might be more successful in generating groundbreaking innovations. Moreover, research on the outcome of bankfintech alliances would contribute to the recent strand of literature on servitization that investigates the stability and ultimate performance of alliances (Das and Teng 2000; Sjödin et al. 2019; Sklyar et al. 2019). The financial industry is particularly fitting to explore in this respect, because national and supranational regulations are likely to affect the scope, organizational form, and, thus, stability of these alliances. 
Second, our study also provides an avenue for future research on servitization (Rabetino et al. 2018). While many banks are currently experimenting with new services, services packages, and alliances with startup firms from the financial ecosystem, whether and how they can systematically develop new services (Bullinger et al. 2003) and how they should combine organizational, technological, and human factors to develop profitable services (Spohrer et al. 2007; Vargo and Lusch 2011) are not clear. Answering these questions likely requires indepth case studies on individual bank-fintech alliances. Our analysis provides first hints that organizations' toplevel management leads corporate change. However, research is still required to investigate whether toplevel management can carry this change process successfully to intermediate- and lower-level managers, who are ultimately in charge of executing the implementation of new digital services and selling them to existing and new clients.

A third future research avenue pertains to the point raised previously that while we consider correlations in our analysis, we do not claim causality. Banks could establish a CDO position because they plan to form alliances in the near future, which would suggest that causality can also go in the opposite direction from what we suggest. Future research might uncover an exogenous shock that would help establish a clean identification strategy for empirical work on causality. Fourth, although we relied on various sources of information to identify alliances, we acknowledge that other sources of information remain invisible to the market, preventing us from identifying all of them. As such, our figures on the number of alliances are lower bounds. Finally, our analysis takes the perspective of banks. Complementary research could explore the perspective of fintech startups' incentives to collaborate with banks. This perspective is likely to be quite different, as fintechs' driving force for forming alliances is often to gain access to banks' large customer base, rather than novel technologies that help foster digital services. This stream of research might uncover why certain digital services are more conducive to development by fintechs rather than by large incumbents.

Acknowledgments The authors thank Luca Enriques, Alvaro Martin Enriquez, Gerard Hertig, Georg Ringe, Egle Vaznyte, Dirk Zetzsche, Kristin Van Zwieten, and the participants of the 5th Crowdinvesting Symposium (Humboldt University Berlin), the 4th International Conference on the Dynamics of Entrepreneurship (Mannheim University), the International Workshop on Financial
System Architecture \& Stability (Cass Business School), the 4th Luxembourg FinTech Conference (University of Luxembourg, Banque Internationale à Luxembourg (BIL) and the Luxembourg House of Financial Technology (LHoFT)), the EBI Global Annual Conference on Banking Regulation (Goethe University, European Stability Mechanism (ESM) and Institute for Monetary and Financial Stability (IMFS)), the 26th Annual Meeting of the German Finance Association (DGF) (University of Duisburg-Essen), the 4th Oxford Business Law Blog Annual Conference, and the 1st International FinTech, InsurTech \& Blockchain Forum (University of Zurich), where the paper received the best paper award, for their valuable comments and suggestions. They also thank Mareike Staufenbiel and Robert Platow for their research assistance.

Funding Information Open Access funding provided by Projekt DEAL.

Open Access This article is licensed under a Creative Commons Attribution 4.0 International License, which permits use, sharing, adaptation, distribution and reproduction in any medium or format, as long as you give appropriate credit to the original author(s) and the source, provide a link to the Creative Commons licence, and indicate if changes were made. The images or other third party material in this article are included in the article's Creative Commons licence, unless indicated otherwise in a credit line to the material. If material is not included in the article's Creative Commons licence and your intended use is not permitted by statutory regulation or exceeds the permitted use, you will need to obtain permission directly from the copyright holder. To view a copy of this licence, visit http://creativecommons.org/licenses/by/4.0/.

\section{References}

Aghion, P., \& Bolton, P. (1992). An incomplete contracts approach to financial contracting. The Review of Economic Studies, 59(3), 473-494. https://doi.org/10.2307/2297860.

Amici, A., Fiordelisi, F., Masala, F., Ricci, O., \& Sist, F. (2013). Value creation in banking through strategic alliances and joint ventures. Journal of Banking and Finance, 37(5), 13861396. https://doi.org/10.1016/j.jbankfin.2012.03.028.

Autio, E., Nambisan, S., Thomas, L. D. W., \& Wright, M. (2018). Digital affordances, spatial affordances, and the genesis of entrepreneurial ecosystems. Strategic Entrepreneurship Journal, 12(1), 72-95. https://doi.org/10.1002/sej.1266.

Baines, T. S., Lightfoot, H., Peppard, J., Johnson, M., Tiwari, A., Shehab, E., \& Swink, M. (2009). Towards an operations strategy for product-centric servitization. International Journal of Operations \& Production Management, 29(5), 494-519. https://doi.org/10.1108/01443570910953603.

Barrett, M., Davidson, E., Prabhu, J., \& Vargo, S. (2015). Service innovation in the digital age: key contributions and future directions. MIS Quarterly: Management Information Systems, 39(1), 135-154. https://doi.org/10.25300 /MISQ/2015/39:1.03.

Beck, T., Chen, T., Lin, C., \& Song, F. M. (2016). Financial innovation: the bright and the dark sides. Journal of Banking and Finance, 72, 25-51. https://doi.org/10.1016/j. jbankfin.2016.06.012. 
Borah, A., \& Tellis, G. J. (2014). Make, buy, or ally? Choice of and payoff from announcements of alternate strategies for innovations. Marketing Science, 33, 114-133. https://doi. org/10.1287/mksc.2013.0818.

Brandl, B., \& Hornuf, L. (2020). Where did Fintechs come from, and where do they go? The transformation of the financial industry in Germany after digitalization. Frontiers in Artificial Intelligence, 3(1), 1-12. https://doi.org/10.3389 /frai.2020.00008.

Brown, S. J., \& Warner, J. B. (1980). Measuring security price performance. Journal of Financial Economics, 8(3), 205258. https://doi.org/10.1016/0304-405X(80)90002-1.

Brown, S. J., \& Warner, J. B. (1985). Using daily stock returns. Journal of Financial Economics, 14(1), 3-31. https://doi. org/10.1016/0304-405X(85)90042-X.

Bullinger, H.-J., Fähnrich, K.-P., \& Meiren, T. (2003). Service engineering-methodical development of new service products. International Journal of Production Economics, 85(3), 275-287. https://doi.org/10.1016/S0925-5273(03)00116-6.

Chiou, I., \& White, L. J. (2005). Measuring the value of strategic alliances in the wake of a financial implosion: evidence from Japan's financial services sector. Journal of Banking \& Finance, 29(10), 2455-2473. https://doi.org/10.1016/J. JBANKFIN.2004.09.001.

Coase, R. H. (1937). The nature of the firm. Economica, 4(16), 386-405. https://doi.org/10.1111/j.1468-0335.1937.tb00002. $\mathrm{x}$.

Coase, R. H. (1960). The problem of social cost. The Journal of Law \& Economics, 3, 1-44 Retrieved from http://www.jstor. org/stable/724810.

Coreynen, W., Matthyssens, P., \& Van Bockhaven, W. (2017). Boosting servitization through digitization: pathways and dynamic resource configurations for manufacturers. Industrial Marketing Management, 60, 42-53. https://doi. org/10.1016/j.indmarman.2016.04.012.

Cumming, D. J., \& Schwienbacher, A. (2018). Fintech venture capital. Corporate Governance: An International Review, 26(5), 374-389. https://doi.org/10.1111/corg.12256.

Das, T. K., \& Teng, B.-S. (2000). Instabilities of strategic alliances: an internal tensions perspective. Organization Science, 11(1), 77-101. https://doi.org/10.1287/orsc.11.1.77.12570.

Demirguc-Kunt, A., \& Levine, R. (1999). Bank-based and marketbased financial systems - cross-country comparisons. Policy Research Working Paper No. 2143. Washington, DC: The World Bank Retrieved from http://documents.worldbank. org/curated/en/259341468739463577/pdf/multi-page.pdf.

European Banking Authority. (2017). Discussion paper on the EBA's approach to financial technology (FinTech). London: Retrieved from http://www.eba.europa.eu/documents/10180 /1919160/EBA+Discussion+Paper+on+Fintech+\%28EBADP-2017-02\%29.pdf.

Geiger, M. A., \& North, D. S. (2006). Does hiring a new CFO change things? An investigation of changes in discretionary accruals. The Accounting Review, 81(4), 781-809. https://doi. org/10.2308/accr.2006.81.4.781.

Gleason, K. C., Mathur, I., \& Wiggins III, R. A. (2003). Evidence on value creation in the financial services industries through the use of joint ventures and strategic alliances. The Financial Review, 38(2), 213-234. https://doi.org/10.1111/15406288.00043 .
Grossman, S. J., \& Hart, O. D. (1986). The costs and benefits of ownership: a theory of vertical and lateral integration. Journal of Political Economy, 94(4), 691-719. https://doi. org/10.1086/261404.

Haddad, C., \& Hornuf, L. (2019). The emergence of the global fintech market: economic and technological determinants. Small Business Economics, 53(1), 81-105. https://doi. org/10.1007/s11187-018-9991-x.

Hagedoorn, J., \& Duysters, G. (2002). External sources of innovative capabilities: the preferences for strategic alliances or mergers and acquisitions. Journal of Management Studies, 39(2), 167-188. https://doi.org/10.1111/1467-6486.00287.

Jacobides, M. G., \& Billinger, S. (2006). Designing the boundaries of the firm: from "make, buy, or ally" to the dynamic benefits of vertical architecture. Organization Science, 17(2), 249261. https://doi.org/10.1287/orsc.1050.0167.

Jiang, X., \& Li, Y. (2009). An empirical investigation of knowledge management and innovative performance: the case of alliances. Research Policy, 38(2), 358-368. https://doi. org/10.1016/j.respol.2008.11.002.

Jiang, X. J., Petroni, K. R., \& Wang, I. Y. (2010). CFOs and CEOs: who have the most influence on earnings management? Journal of Financial Economics, 96(3), 513-526. https://doi.org/10.1016/j.jfineco.2010.02.007.

Klus, M. F., Lohwasser, T. S., Holotiuk, F., \& Moormann, J. (2019). Strategic alliances between banks and fintechs for digital innovation: motives to collaborate and types of interaction. Journal of Entrepreneurial Finance, 21(1), 1-23.

Kohtamäki, M., Parida, V., Oghazi, P., Gebauer, H., \& Baines, T. (2019). Digital servitization business models in ecosystems: a theory of the firm. Journal of Business Research, 104, 380392. https://doi.org/10.1016/j.jbusres.2019.06.027.

Kohtamäki, M., Parida, V., Patel, P. C., \& Gebauer, H. (2020). The relationship between digitalization and servitization: the role of servitization in capturing the financial potential of digitalization. Technological Forecasting and Social Change, 151, 119804. https://doi.org/10.1016/j.techfore.2019.119804.

Lerner, J. (2002). Where does state street lead? A first look at finance patents, 1971 to 2000. The Journal of Finance, 57(2), 901-930. https://doi.org/10.1111/1540-6261.00446.

Lerner, J., Speen, A., Baker, M., \& Leamon, A. (2015). Financial patent quality: finance patents after state street. Harvard Business School Working Paper No. 16-068. Cambridge, MA. Retrieved from https://www.hbs. edu/faculty/Pages/item.aspx?num=50238.

Li, K., Qiu, J., \& Wang, J. (2019). Technology conglomeration, strategic alliances, and corporate innovation. Management Science, 65(11), 5065-5090. https://doi.org/10.1287 /mnsc.2018.3085.

Marciukaityte, D., Roskelley, K., \& Wang, H. (2009). Strategic alliances by financial services firms. Journal of Business Research, 62(11), 1193-1199. https://doi.org/10.1016/J. JBUSRES.2008.07.004.

Merton, R. C. (1995). Financial innovation and the management and regulation of financial institutions. Journal of Banking \& Finance, 19(3-4), 461-481. https://doi.org/10.1016/03784266(94)00133-N.

Miller, M. H. (1986). Financial innovation: the last twenty years and the next. The Journal of Financial and Quantitative Analysis, 21(4), 459-471. https://doi.org/10.2307/2330693. 
MSCI. (2018). MSCI Germany Index (USD). Retrieved January 14, 2019, from https://www.msci.com/documents/10199 /d76361cb-d5a5-4185-97ce-ec5e3dd5bf2e.

Navaretti, G. B., Calzolari, G., Mansilla-Fernandez, J. M., \& Pozzolo, A. F. (2017). Fintech and banking. Friends or foes? European Economy - banks, regulation, and the real sector, 2017.2 (pp. 9-30). https://european-economy.eu/20172/fintech-and-banks-friends-or-foes/?did=2045.

Peng, J.-L., Jeng, V., Wang, J. L., \& Chen, Y.-C. (2017). The impact of bancassurance on efficiency and profitability of banks: evidence from the banking industry in Taiwan. Journal of Banking \& Finance, 80, 1-13. https://doi. org/10.1016/J.JBANKFIN.2017.03.013.

Puschmann, T. (2017). Fintech. Business \& Information Systems Engineering, 59(1), 69-76. https://doi.org/10.1007/s12599017-0464-6.

Rabetino, R., Harmsen, W., Kohtamäki, M., \& Sihvonen, J. (2018). Structuring servitization-related research. International Journal of Operations \& Production Management, 38(2), 350-371. https://doi.org/10.1108 /IJOPM-03-2017-0175.

Sakao, T., \& Shimomura, Y. (2007). Service engineering: a novel engineering discipline for producers to increase value combining service and product. Journal of Cleaner Production, 15(6), 590-604. https://doi.org/10.1016/j. jclepro.2006.05.015.

Scott, S. V., Van Reenen, J., \& Zachariadis, M. (2017). The longterm effect of digital innovation on bank performance: an empirical study of SWIFT adoption in financial services. Research Policy, 46(5), 984-1004. https://doi.org/10.1016/j. respol.2017.03.010.

Sjödin, D., Parida, V., \& Kohtamäki, M. (2019). Relational governance strategies for advanced service provision: multiple paths to superior financial performance in servitization. Journal of Business Research, 101, 906-915. https://doi. org/10.1016/j.jbusres.2019.02.042.
Sklyar, A., Kowalowski, C., Tronvoll, B., \& Sorhammar, D. (2019). Organizing for digital servitization: a service ecosystem perspective. Journal of Business Research, 104, 450 460. https://doi.org/10.1016/j.jbusres.2019.02.012.

Spohrer, J., \& Maglio, P. P. (2010). Toward a science of service systems: value and symbols. In P. P. Maglio, J. A. Kieliszewski, \& J. C. Spohrer (Eds.), Handbook of service science (pp. 157-194). New York: Springer. https://doi. org/10.1007/978-1-4419-1628-0_9.

Spohrer, J., Maglio, P. P., Bailey, J., \& Gruhl, D. (2007). Steps toward a science of service systems. Computer, 40(1), 71-77. https://doi.org/10.1109/MC.2007.33.

Teece, D. J. (1986). Profiting from technological innovation: implications for integration, collaboration, licensing and public policy. Research Policy, 15(6), 285-305. https://doi. org/10.1016/0048-7333(86)90027-2.

Vargo, S. L., \& Lusch, R. F. (2011). It's All B2B...and beyond: toward a systems perspective of the market. Industrial Marketing Management, 40(2), 181-187. https://doi. org/10.1016/j.indmarman.2010.06.026.

Vendrell-Herrero, F., Bustinza, O. F., Parry, G., \& Georgantzis, N. (2017). Servitization, digitization and supply chain interdependency. Industrial Marketing Management, 60, 69-81. https://doi.org/10.1016/j.indmarman.2016.06.013.

Williamson, O. E. (1991). Strategizing, economizing, and economic organization. Strategic Management Journal, 12, 75-94. https://doi.org/10.1002/smj.4250121007.

Yoo, Y., Henfridsson, O., \& Lyytinen, K. (2010). Research commentary - the new organizing logic of digital innovation: an agenda for information systems research. Information Systems Research, 21(4), 724-735. https://doi.org/10.1287 /isre.1100.0322.

Publisher's note Springer Nature remains neutral with regard to jurisdictional claims in published maps and institutional affiliations. 